Research Article

\title{
Genetic analysis of scattered populations of the Indian eri silkworm, Samia cynthia ricini Donovan: Differentiation of subpopulations
}

Appukuttannair R. Pradeep ${ }^{1 *}$, Anuradha H. Jingade ${ }^{1 \#}$, Choba K. Singh ${ }^{2 \$}$, Aravind K. Awasthi ${ }^{1}$, Vikas Kumar ${ }^{1}$, Guruprasad C. Rao ${ }^{1}$ and N.B. Vijaya Prakash ${ }^{1}$

${ }^{1}$ Seribiotech Research Laboratory, CSB Campus, Carmelaram P.O., Bangalore, Karnataka, India.

${ }^{2}$ Central Eri Muga Research and Training Institute, Ladoigarh, Jorhat, Assam, India.

\begin{abstract}
Deforestation and exploitation has led to the fragmentation of habitats and scattering of populations of the economically important eri silkworm, Samia cynthia ricini, in north-east India. Genetic analysis of 15 eri populations, using ISSR markers, showed $98 \%$ inter-population, and $23 \%$ to $58 \%$ intra-population polymorphism. Nei's genetic distance between populations increased significantly with altitude $\left(R^{2}=0.71\right)$ and geographic distance $\left(R^{2}=0.78\right)$. On the dendrogram, the lower and upper Assam populations were clustered separately, with intermediate grouping of those from Barpathar and Chuchuyimlang, consistent with geographical distribution. The Nei's gene diversity index was 0.350 in total populations and 0.121 in subpopulations. The genetic differentiation estimate (Gst) was 0.276 among scattered populations. Neutrality tests showed deviation of 118 loci from Hardy-Weinberg equilibrium. The number of loci that deviated from neutrality increased with altitude $\left(R^{2}=0.63\right)$. Test of linkage disequilibrium showed greater contribution of variance among eri subpopulations to total variance. $D^{2} I S$ exceeded $D^{2} S T$, showed significant contribution of random genetic drift to the increase in variance of disequilibrium in subpopulations. In the Lakhimpur population, the peripheral part was separated from the core by a genetic distance of 0.260 . Patchy habitats promoted low genetic variability, high linkage disequilibrium and colonization by new subpopulations. Increased gene flow and habitat-area expansion are required to maintain higher genetic variability and conservation of the original S. c. ricini gene pool.
\end{abstract}

Key words: subpopulation differentiation, scattered population, Samia cynthia ricini, ISSR loci, gene diversity.

Received: October 21, 2010; Accepted: May 4, 2011.

\section{Introduction}

The Indian eri silkworm, Samia cynthia ricini $(=S$. ricini Donovan; Lepidoptera: Saturniidae) is a domesticated silkworm that feeds primarily on leaves of the castor plant, Ricinus communis L. This species, initially reported from the foot-hills of Himalaya, was later introduced into temperate countries. For more than a century, a few populations have been used for commercial silk production in northeast India, in such regions as the Brahmaputra river valley, east and west Garo Hills, east and west Khasi Hills, Nagaland and Manipur (Singh and Benchamin, 2002; Piegler and Naumann, 2003). Primary and secondary food plants occur in abundance in the surroundings characterized by temperatures of $7^{\circ} \mathrm{C}$ to $34^{\circ} \mathrm{C}$ and an average annual rainfall of $2800 \mathrm{~mm}$. Fifteen populations of the eri silk-

Send correspondence to A.R. Pradeep. Seribiotech Research Laboratory, CSB Campus, Carmelaram P.O., Bangalore 560035 Karnataka, India. E-mail: arpradeep23@ rediffmail.com.

"Present address: Central Silkworm Germplasm Resource Center, Hosur, Tamil Nadu, India.

\$Present address: Regional Tasar Research Station, Mantripukhri, Imphal, Manipur, India. worm were recognized from localities at various altitudes ranging from 35 to 925 meters above sea level (MSL) (Table 1). Although morphological characterization indicated phenotypic variability, molecular data on genetic relations and structure are required to improve the population characterization. Recently, the species was identified as a potential source for exploring functional genomics (Arunkumar et al., 2008), although prior to their use in assessing genetic diversity, variations in EST and putative gene expression need to be ascertained. The lack of co-dominant markers, such as microsatellites from the eri silkworm itself, has added to the problem when analyzing population genetic status.

Inter simple-sequence repeat (ISSR) primers were designed from regions of microsatellite abundance in the genome, which exhibit high level of polymorphism (Schlotterer, 2000). As ISSR, the dominant marker system is simpler to use though not entailing prior information on target regions (Zietkiewicz et al., 1994; Nagaraju et al., 2002), it has been extensively employed for identifying inter-and intra-populational genetic variability in several insect species, including domestic and wild silkworms (Ehtesham et 
Table 1 - Geographical characters of the place of collection of 15 populations of the eri silkworm, Samia cynthia ricini from north-eastern states of India.

\begin{tabular}{lccccccc}
\hline Code & Population & State & District & Latitude & Longitude & Altitude* & Physiography \\
\hline E1 & Barpathar & Assam & Golaghat & $26^{\circ} 20^{\prime} \mathrm{N}$ & $93^{\circ} 36^{\prime} \mathrm{E}$ & $99 \mathrm{~m}$ & Flat terrain \\
E2 & Chuchuyimlang & Nagaland & Makokchung & $26^{\circ} 20^{\prime} \mathrm{N}$ & $94^{\circ} 31^{\prime} \mathrm{E}$ & $925 \mathrm{~m}$ & Hilly terrain \\
E3 & Borduar & Assam & Kamrup & $25^{\circ} 55^{\prime} \mathrm{N}$ & $90^{\circ} 38^{\prime} \mathrm{E}$ & $61 \mathrm{~m}$ & Flat plain \\
E4 & Khanapara & Assam & Kamrup & $26^{\circ} 23^{\prime} \mathrm{N}$ & $91^{\circ} 51^{\prime} \mathrm{E}$ & $78 \mathrm{~m}$ & Flat terrain \\
E5 & Titabar & Assam & Jorhat & $26^{\circ} 60^{\prime} \mathrm{N}$ & $94^{\circ} 20^{\prime} \mathrm{E}$ & $104 \mathrm{~m}$ & Flat terrain \\
E6 & Nongpoh & Meghalaya & Ribhoi & $25^{\circ} 46^{\prime} \mathrm{N}$ & $91^{\circ} 46^{\prime} \mathrm{E}$ & $525 \mathrm{~m}$ & Hilly terrain \\
E7 & Dhanubhanga & Assam & Goalpara & $25^{\circ} 09^{\prime} \mathrm{N}$ & $91^{\circ} 10^{\prime} \mathrm{E}$ & $35 \mathrm{~m}$ & Flat terrain \\
E8 & Mendipathar & Meghalaya & East Garo Hills & $25^{\circ} 52^{\prime} \mathrm{N}$ & $90^{\circ} 38^{\prime} \mathrm{E}$ & $300 \mathrm{~m}$ & Hilly terrain \\
E9 & Imphal & Manipur & Imphal West & $24^{\circ} 38^{\prime} \mathrm{N}$ & $93^{\circ} 37^{\prime} \mathrm{E}$ & $785 \mathrm{~m}$ & Flat terrain \\
E10 & Dhansiripar & Nagaland & Dimapur & $25^{\circ} 54^{\prime} \mathrm{N}$ & $93^{\circ} 44^{\prime} \mathrm{E}$ & $304 \mathrm{~m}$ & Foot Hill \\
E11 & Diphu & Assam & Karbi Anglong & $25^{\circ} 49^{\prime} \mathrm{N}$ & $93^{\circ} 43^{\prime} \mathrm{E}$ & $609 \mathrm{~m}$ & Plateau \\
E12 & Lakhimpur & Assam & Lakhimpur & $27^{\circ} 14^{\prime} \mathrm{N}$ & $94^{\circ} 07^{\prime} \mathrm{E}$ & $102 \mathrm{~m}$ & Flat terrain \\
E13 & Dhemaji & Assam & Dhemaji & $27^{\circ} 49^{\prime} \mathrm{N}$ & $94^{\circ} 58^{\prime} \mathrm{E}$ & $133 \mathrm{~m}$ & Flat terrain \\
E14 & Dhakuakhana & Assam & Lakhimpur & $27^{\circ} 12^{\prime} \mathrm{N}$ & $94.28^{\prime} \mathrm{E}$ & $68 \mathrm{~m}$ & Flat terrain \\
E15 & Cachar & Assam & Cachar & $25^{\circ} 32^{\prime} \mathrm{N}$ & $92^{\circ} 41^{\prime} \mathrm{E}$ & $680 \mathrm{~m}$ & Flat terrain \\
\hline
\end{tabular}

*meters above sea level.

al., 1995; Pradeep et al., 2005, 2007, 2008; Vijayan et al., 2005, 2006; Santana et al., 2009; Saravanakumar et al., 2010). Hence the ISSR marker system has been selected for genetic analysis of the eri populations.

On route, many unexploited eri populations from remote areas of northeast India were identified. Habitats were isolated by high mountains, farm land and human dwellings, all leading to the formation of patchy inbred populations. Habitat fragmentation had deleteriously affected the genetic structure of natural populations (Hale et al., 2001), thus causing a loss in biological diversity (Davies et al., 2001). Furthermore, commercial exploitation gave rise to gene-pool mixing, thus contributing to the loss of population identity. Genetic analysis of these scattered populations using molecular markers becomes imperative, in order to develop a sustainable strategy for conserving the various genetic resources as yet available. The aim was to analyze the genetic structure of unexploited, scattered eri populations, as well as the genetic interaction with topographic features of collection sites. The data demonstrated a loss of genetic diversity in sub-populations, as well as the genetic reorganization of certain populations, which can be considered as markers of eco-genetic consequences on insects undergoing regional habitat fragmentation.

\section{Materials and Methods}

\section{DNA extraction and PCR}

Fifteen populations of S.c.ricini, duly named after their place of origin, were collected from coincident locations at different altitudes in northeast India, viz., Barpathar (E1), Chuchuyimlang (E2), Borduar (E3), Khanapara (E4), Titabar (E5), Nongpoh (E6), Dhanubhanga (E7), Mendi- pathar (E8), Imphal (E9), Dhansiripar (E10), Diphu (E11), Lakhimpur (E12), Dhemaji (E13), Dhakuakhana (E14) and Cachar (E15). Cocoons ( $n=200$ each or more) were collected, and transferred to the germplasm station located at the Central Eri Muga Research and Training Institute, Ladoigarh, Jorhat in Assam State, northeast India. On emergence, 30 moths were randomly collected from each population, and preserved at $-80^{\circ} \mathrm{C}$, prior to DNA extraction.

DNA extracted from individual moths by the phenol:chloroform method (Suzuki et al., 1972), was incubated with RNase A to remove RNA contamination and then re-extracted. The purified DNA was dissolved in Tris-EDTA (TE; pH 8.0) buffer and quantified on $0.8 \%$ agarose gels. PCR amplification was carried out on an MJ Research Thermal-Cycler, PTC 200, using $20 \mu \mathrm{L}$ reaction mixture containing 10x PCR buffer, $2 \mathrm{mM}$ dNTPs, $2.5 \mathrm{mM}$ $\mathrm{MgCl}_{2}, 0.10 \mu \mathrm{L}$ of Taq DNA polymerase (recombinant; Fermentas) $(5 \mathrm{U} / \mu \mathrm{L}), 2.0 \mu \mathrm{L}$ of $1.5 \mu \mathrm{M}$ ISSR primer and $40 \mathrm{ng}$ of DNA. The ISSR primers (set \# 9) were purchased from the Nucleic Acid \& Protein Service of Biotechnology Laboratory (University of British Columbia, Vancouver, Canada). Of the 100 primers tested, only 20 showed reproducible amplification. Each reaction was replicated at least twice for reproducibility. The PCR cycle followed was $94{ }^{\circ} \mathrm{C}$ for 2 min followed by 35 cycles of $94^{\circ} \mathrm{C}$ for $30 \mathrm{~s}$, annealing at $50{ }^{\circ} \mathrm{C}$ for $30 \mathrm{~s}$ and extension at $72{ }^{\circ} \mathrm{C}$ for $2 \mathrm{~min}$ and a final extension at $72{ }^{\circ} \mathrm{C}$ for $10 \mathrm{~min}$. Following PCR, the reaction mixture was loaded on a $1.5 \%$ agarose gel in Tris-Boric acid-EDTA (TBE) buffer and resolved at $60 \mathrm{~V}$ in a submarine electrophoresis system. The gel was illuminated with UV and the ISSR profiles were photographed using a gel documentation system (Syngene). 


\section{Statistical analyses}

Amplification products were scored in a binary mode $(1,0)$, where " 1 " represented the presence of a marker and "0" its absence. The data was analyzed by SPSS 11.5 software and POPGENE version 1.32 (Yeh, 1998). Polymorphism levels were expressed as the percentage of all the loci that proved to be polymorphic in the profile. The null hypothesis was tested with Chi-square $\left(\chi^{2}\right)$ and likelihood ratio $\left(G^{2}\right)$ analysis for each locus, which determined the probability of homozygosity under Hardy-Weinberg equilibrium. The Ewens-Watterson test for neutrality was applied for assessing variation from Hardy-Weinberg equilibrium (H-WE) in 1000 simulated samples. The Nei (1972) genetic distance, the Nei (1973) gene diversity index (h), the Shannon Information index (I) (Lewontin, 1972), observed number of alleles (na), effective number of alleles (ne) (Kimura and Crow, 1964) and coefficient of genetic differentiation (Gst), were estimated using the POPGENE program. According to Nei (1973) genetic diversity statistics, $G$ st, a measure of population differentiation, is defined as the proportion of genetic diversity that resides among populations. Gst values range from zero to one, with low values indicating little inter-population genetic variation (Culley et al., 2002). Pair-wise genetic similarity was calculated as $2 \mathrm{Nij} /(\mathrm{N} i+\mathrm{N} j)$, where $\mathrm{N} i j$ is the number of common bands in $i$ and $j$ populations, and $\mathrm{N} i$ and $\mathrm{N} j$ the total number of bands produced by the populations $i$ and $j$ (Nei and Li, 1979). A phylogeny tree was constructed based on the dissimilarity (1-similarity value) matrix, using cluster analysis by UPGMA (Unweighted Pair Group Method using an Arithmetic average), available in the clustering program, PHYLIP version 9.0. Bootstrap analysis was performed using 10000 replicates as provided in PAUP* software (Swofford, 1998).

Linkage disequilibrium among pairs of loci for each population was calculated using ISSR loci that deviated from HWE, according to Weir (1979). Non-random association between two loci was assessed by Chi-square testing. Variance components of linkage disequilibrium were calculated by two-locus analysis, as per D - Statistics of Ohta (1982). Total variance $\left(\mathrm{D}^{2} \mathrm{IT}\right)$ was partitioned into intra$\left(\mathrm{D}^{2} \mathrm{IS}, \mathrm{D}^{2} \mathrm{IS}\right)$ and inter- $\left(\mathrm{D}^{2} \mathrm{ST}, \mathrm{D}^{2} \mathrm{ST}\right)$ population components, both calculated with POPGENE software.

Relation between genotypic parameters and geographical parameters of the site of collection was analyzed by linear regression analysis and correlation coefficient $\left(\mathrm{R}^{2}\right)$.

The distribution pattern of individuals within each population was analyzed by ALSCAL multidimensional scaling available in the SPSS program. In this analysis, the genetic distance was computed and a dissimilarity matrix created, using Euclidean distances acquired from the ISSR profile. Euclidean distance was used for data stimulus configuration, using the classical Young-Householder multidimensional scaling procedure (Young et al., 1984; Young and Harris, 1990). Canonical discriminant function analysis (DFA, as given in the SPSS program) was applied for analyzing the contribution of altitude to the genetic status of eri populations, by using altitude and ISSR loci for defining the percentage of variance of the dependent variable (altitude), as inferred from independent loci. Altitudes were categorized as class 1; 0-100 MSL, class 2; 101-200 and so on. The multivariate stepwise approach, with the same limit of $F$ value for stepwise entry and removal of variables (ISSR loci in this case), was used for calculating Mahalanobis distance $\left(D^{2}\right)$ statistics, and arriving at estimates of Chi-square and Wilks' Lambda (Anderson, 1984; Introna Jr et al., 1997). For DFA, squared Mahalanobis distance $\left(D^{2}\right)$ was used for testing the distance from the group centroid in each case. The shorter the distance, the closer the case was to the group itself, and thus more likely for classification as belonging thereto (Mahalanobis, 1936).

\section{Results}

\section{Phenotypic variability}

Of the 15 S.c.ricini populations, eight were from lower (35-150 MSL), two from mid- ( $300 \mathrm{MSL})$ and five from higher (500-925 MSL) altitudes (Table 1). Eri larvae have a distinct blue or yellow body-color, with or without zebra markings, and spines. The color of the cocoons produced by the various populations was either white or brick-red, or both.

\section{Inter population genetic status}

Twenty ISSR primers amplified 194 products from genomic DNA of the 15 populations within a size range of $0.3 \mathrm{~kb}$ to $3.0 \mathrm{~kb}$. The UBC 842 primer produced 15 bands, the maximum, whereas UBC807 and UBC812 produced only five, the minimum. According to AMOVA, inter-population polymorphism was $98 \%$. The Nei (1972) genetic distance was the highest between Dhemaji and Dhanubhanga (0.593), and the lowest between Dhakuakhana and Cachar (0.0686). The average genetic distance among the Lakhimpur, Dhemaji and Dhakuakhana populations located in close proximity (an average distance of $21 \mathrm{~km}$ ) in the Brahmaputra river basin in upper Assam, was 0.109, and between these populations and those geographically farther placed was 0.442 . The geographic distance between Mendipathar and Cachar was $915 \mathrm{~km}$ and the genetic distance 0.413 . Regression of genetic distances between populations over geographical distances, revealed significant positive correlation $\left(\mathrm{R}^{2}=0.783 ; \mathrm{p}<0.0009 ; \mathrm{Y}=0.0009 \mathrm{X}\right.$ $+0.121)$.

According to the dendrogram plotted from the ISSR profile, the Lakhimpur, Dhemaji, Dhakuakhana and Cachar populations were distinctly clustered, whereas the Barpathar and Chuchuyimlang were grouped together. The Diphu and Dhansiripar populations were grouped together with commercial populations (E3 to E8). Tree-branching in 
the dendrogram was strongly supported by significantly high bootstrap values. At the node representing Barpathar and Chuchuyimlang clustering, bootstrap value was $87 \%$. On plotting the phylogeny tree onto a geographical map of the collection sites, the Barpathar and Chuchuyimlang populations were found to be at an intermediate position in a north-south direction, both on the map itself and the phylogram (Figure 1).

Analysis of genetic variability revealed low gene diversity throughout both the total eri population $(\mathrm{Ht}=0.350 \pm 0.019)$ and subpopulations $(\mathrm{Hs}=$ $0.121 \pm 0.008$ ). Among loci, UBC808-7 1200 bp and UBC885$11_{550 \mathrm{bp}}$ presented the highest $\mathrm{Ht}$ of 0.42 . The coefficient of genetic differentiation (Gst) was lower among the scattered non-commercial populations than among the commercial (Table 2). In the total eri population, gene flow was 0.263 . The contribution of ISSR loci to population heterogeneity was assessed by Chi-square analysis. Out of the 194 loci, 10 showed significant probability $\left(\left(\chi^{2}\right) / \mathrm{g}^{2}<0.05\right.$ or better $)$ values indicative of a significant contribution $(\mathrm{p}<0.01$ or better).

Locus-variation from H-WE was examined by the Ewens-Watterson test for neutrality. Deviation occurred in 118 loci (Table 3), with 77 loci had the F-values above the upper limit of expectancy ( $95 \%$ confidence), and 41 below the lower limit. Linkage disequilibrium was calculated for the total population, in order to assess the contribution of non-selective forces on the fluctuation of loci from HWE. Single population linkage disequilibrium analysis (Weir 1979) showed significant $(p<0.05)$ disequilibrium in S.c.ricini populations. In populations from areas of low altitude $(<200 \mathrm{MSL})$, linkage disequilibrium was more pronounced when compared to those from higher altitudes. Total variance $\left(\mathrm{D}^{2} \mathrm{IT}\right)$ of the disequilibrium (Ohta, 1982) was 0.2601 . D ${ }^{\prime 2} \mathrm{IS}(0.2416)$ was greater than $\mathrm{D}^{\prime 2} \mathrm{ST}$ (0.0185), an indication of close-to-zero variance in the total population, and consequently the more pronounced inde-

Table 2 - ISSR polymorphism and population genetic characteristics of total, commercial and non- commercial scattered populations of the eri silkworm, Samia cynthia ricini.

\begin{tabular}{|c|c|c|c|c|c|c|c|}
\hline Population category & $\%$ Polymorphism & $\mathrm{Ht}$ & Hs & $\mathrm{Gst}^{+}$ & $\mathrm{Nm}^{*}$ & $\mathrm{~h}^{* *}$ & $I^{* * *}$ \\
\hline Non-commercial scattered (E1,E2,E9-E15) & 97.94 & $0.3445 \pm 0.1225$ & $0.6444 \pm 0.0242$ & 0.2759 & 1.312 & 0.0879 & 0.1288 \\
\hline Commercial (E3-E8) & 78.35 & $0.2479 \pm 0.0345$ & $0.1186 \pm 0.0158$ & 0.5216 & 0.459 & 0.2483 & 0.3766 \\
\hline Total & 100 & $0.3505 \pm 0.0195$ & $0.1209 \pm 0.0078$ & 0.6550 & 0.263 & - & - \\
\hline
\end{tabular}

E1-E15 populations as given in Table $1 ;{ }^{+}$Gst $=$genetic differentiation estimate; $*$ Nm = estimate of gene flow from Gst. $(\mathrm{Nm}=0.5(1-\mathrm{Gst}) / \mathrm{Gst}$.$) ;$ $* * \mathrm{~h}=$ Nei's (1973) gene diversity index; *** I = Shannon's Information index.

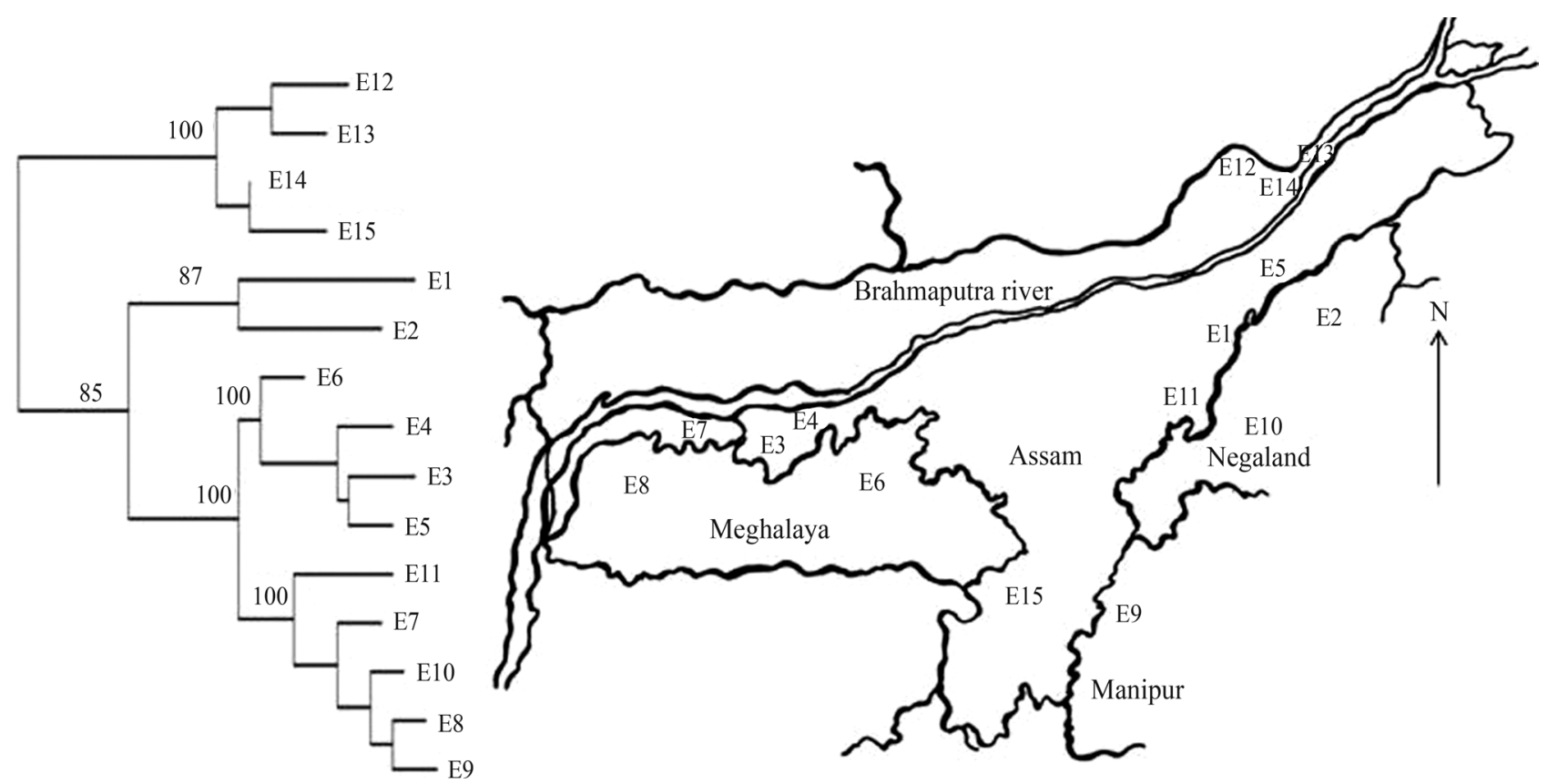

Figure 1 - Mapping of the phylogeny tree to geographical map of the collection sites of 15 populations (E1 - E15) of Samia cynthia ricini from north-east India. These are as depicted in Table 1. Note the intermediate position of the Barpathar (E1) and Chuchuyimlang (E2) populations in north-south direction between the upper and lower Assam populations, both on the dendrogram and map. Bootstrap values coincide with dendrogram nodes. The states where collections occurred are indicated (Schematic map, not to scale). 
Table 3 - ISSR polymorphism, Nei (1973) gene diversity, average genetic distance and loci selected by Ewans-Watterson test of neutrality of 15 populations of the eri silkworm, Samia cynthia ricini.

\begin{tabular}{|c|c|c|c|c|c|c|c|c|}
\hline \multirow[t]{2}{*}{ Population } & \multirow[t]{2}{*}{$\begin{array}{c}\text { Polymorphism } \\
(\%)\end{array}$} & \multirow[t]{2}{*}{$\mathrm{h}^{\#}$} & \multirow[t]{2}{*}{$I^{\# \#}$} & \multirow[t]{2}{*}{ na } & \multirow[t]{2}{*}{ ne } & \multirow{2}{*}{$\begin{array}{l}\text { Average genetic } \\
\text { distance within } \\
\text { population }\end{array}$} & \multicolumn{2}{|c|}{$\begin{array}{l}\text { Number of loci varied from } \\
\text { H-WE with: }\end{array}$} \\
\hline & & & & & & & Higher value $\mathrm{e}^{\# \#}$ & Lower value \\
\hline Barpathar* & 42.78 & 0.1608 & 0.2363 & $1.286 \pm 0.390$ & $1.286 \pm 0.390$ & 0.253 & 5 & 0 \\
\hline Chuchuyimlang* & 26.80 & 0.0922 & 0.1381 & $1.157 \pm 0.302$ & $1.157 \pm 0.302$ & 0.179 & 3 & 0 \\
\hline Borduar\$ & 30.41 & 0.1114 & 0.1645 & $1.197 \pm 0.346$ & $1.197 \pm 0.346$ & 0.208 & 1 & 3 \\
\hline Khanapara\$ & 32.47 & 0.1241 & 0.1818 & $1.220 \pm 0.360$ & $1.220 \pm 0.360$ & 0.213 & 2 & 0 \\
\hline Titabar\$ & 34.54 & 0.1383 & 0.2001 & $1.252 \pm 0.388$ & $1.252 \pm 0.388$ & 0.211 & 5 & 1 \\
\hline Nongpho\$ & 28.35 & 0.1072 & 0.1579 & $1.188 \pm 0.338$ & $1.188 \pm 0.338$ & 0.189 & 2 & 6 \\
\hline Dhanubhanga\$ & 33.51 & 0.1258 & 0.1858 & $1.219 \pm 0.350$ & $1.219 \pm 0.350$ & 0.225 & 0 & 6 \\
\hline Mendipathar\$ & 28.87 & 0.1048 & 0.1557 & $1.182 \pm 0.329$ & $1.182 \pm 0.329$ & 0.229 & 2 & 1 \\
\hline Imphal* & 41.24 & 0.1437 & 0.2140 & $1.250 \pm 0.362$ & $1.250 \pm 0.362$ & 0.275 & 4 & 4 \\
\hline Dhansirpar* & 37.63 & 0.1387 & 0.2042 & $1.245 \pm 0.368$ & $1.245 \pm 0.368$ & 0.253 & 4 & 3 \\
\hline Diphu* & 32.47 & 0.1116 & 0.1663 & $1.193 \pm 0.332$ & $1.193 \pm 0.332$ & 0.246 & 9 & 0 \\
\hline Lakhimpur* & 58.25 & 0.1545 & 0.2378 & $1.258 \pm 0.344$ & $1.258 \pm 0.344$ & 0.218 & 36 & 4 \\
\hline Dhemaji* & 22.68 & 0.0879 & 0.1288 & $1.155 \pm 0.314$ & $1.155 \pm 0.314$ & 0.191 & 1 & 2 \\
\hline Dhakuakhana* & 29.90 & 0.1155 & 0.1697 & $1.202 \pm 0.342$ & $1.202 \pm 0.342$ & 0.291 & 0 & 3 \\
\hline Cachar* & 28.87 & 0.0976 & 0.1463 & $1.168 \pm 0.317$ & $1.168 \pm 0.317$ & 0.262 & 3 & 8 \\
\hline
\end{tabular}

${ }^{\#} \mathrm{~h}$ and ${ }^{\# \#} \mathrm{I}$ are as given under Table 2; na = Observed number of alleles; ne = Effective number of alleles (Kimura and Crow, 1964); ${ }^{\# \#}$ Outlier loci with values higher or lower than the lower and upper limits of $95 \%$ confidence region of expected F value; \$Commercial populations; *Non-commercial populations.

pendence of loci. On the other hand, $\mathrm{D}^{2} \mathrm{ST}(0.258)$ was greater than $\mathrm{D}^{2} \mathrm{IS}(0.0022)$, thus indicating that a larger proportion of total variance in disequilibrium resulted from deviation "among the subpopulations" than that from "within populations".

\section{Intra-population genetic status}

Intra-population polymorphism was the highest in the Lakhimpur (58\%) and the lowest in the Dhemaji and Chuchuyimlang (22\% and $26 \%$, respectively) (Table 3$)$. In the Lakhimpur, 113 loci were polymorphic, as against 62 in the Cachar. Nei's intra-population gene diversity (h) was the highest in the Barpathar (0.161) and Lakhimpur (0.155) and the lowest in the Dhemaji (0.088), Cachar (0.098) and Chuchuyimlang (0.092). Generally, gene diversity was somewhat higher in the populations of the lower Assam and Meghalaya regions $(\sim 0.12)$, when compared to the upper Assam and Nagaland regions ( $\sim .11)$. The Shannon Information index (I) was the lowest in the Dhemaji population $(0.12)$ and the highest $(0.238)$ in the Lakhimpur. The observed number of alleles varied from 1.227 in the Dhemaji to 1.583 in the Lakhimpur, whereas the effective number of alleles varied from 1.155 in the Dhemaji to 1.286 in the Barpathar.

Genetic distances were calculated, so as to assess genetic relationships among individuals within each population. These ranged from 0.179 in the Chuchuyimlang to
0.291 in the Dhakuakhana population (Table 3). In Dhemaji and Nongpoh also, the genetic distance among individuals $(\sim 0.190)$ was low.

The distribution of individuals within each population was assessed by ALSCAL multidimensional scaling. Except for Lakhimpur, they were either uniformly distributed on the matrix or clustered in the center (data not shown). Although in the Lakhimpur population (E12), one group of individuals was clustered together (core population), another was separated, thus forming a peripheral group (Figure 2). The average genetic distance among core population individuals was 0.17 , whereas that between clustered and peripheral was 0.26 , thus significantly higher ( $<<0.007$; Student $t$-test). On the dendrogram, individuals of the peripheral population, besides being grouped separately, presented less genetic differentiation (Data not shown).

\section{Relationship between geographic variation and genetic status}

DFA of altitude-dependent genetic variance among the eri populations showed significant $(\mathrm{p}<0.000)$ genetic variance, supported by significant (0.000) Wilk $\lambda$ and Chisquare estimates and large canonical-correlation coefficients $\left(R^{2}=0.996\right)$. The mean genetic distance of high altitude populations, such as those of Diphu, Cachar, Imphal and Chuchuyimlang, from low altitude populations was 


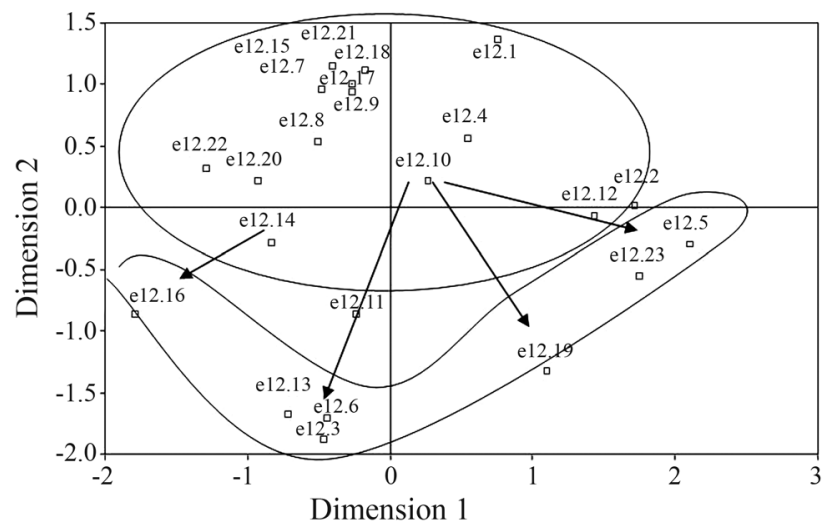

Figure 2 - Spatial distribution of individuals from the Lakhimpur population of Samia cynthia ricini on an ALSCAL matrix, based on Euclidean distance calculated from independent variables, ISSR loci. Individuals of the population were represented as e12.1 to e12.22. Those in a circle represent the core population. Arrows indicate the separation, at a significant genetic distance, of the peripheral population from the core.

0.329. As a whole, genetic distances among eri populations increased with altitude, a clear indication of a significant relationship between the two parameters $\left(\mathrm{R}^{2}=0.71\right.$; $\mathrm{p}<0.004)$. Notwithstanding, genetic distances among individuals within a specific population was not influenced by the prevailing altitude (data not shown). In the high altitude populations of Chuchuyimlang and Cachar, Nei's gene diversity was low $(\sim 0.09)$, whereas in the low altitude, such as Dhanubhanga and Dhakuakhana, it was high $(\sim 0.12)$. The regression of Nei's gene diversity on altitude, revealed only a weak negative correlation between the two parameters $\left(\mathrm{R}^{2}=0.118 ; \mathrm{Y}=-3 \mathrm{E}-05 \mathrm{X}+0.1251\right)$. There was no correlation in populations from Imphal and Dhemaji, as shown by the $\mathrm{R}^{2}$ value decreasing from 0.437 to 0.118 . On assessing the deviation of loci from neutrality, the significant increase in the number of loci that deviated from $\mathrm{H}-\mathrm{WE}$ coincided with the increase in altitude $\left(\mathrm{R}^{2}=0.627\right.$; $\mathrm{Y}=0.0081 \mathrm{X}+3.4111)$.

\section{Discussion}

Infiltration and the use of forest areas for farming and human dwellings have been the cause of forestfragmentation in northeast India. This, besides contributing to genetic erosion, has negatively affected the survival of many flora and fauna species, including the Samia (Piegler and Naumann, 2003). The fragmentation of habitats has induced scattered distribution, geographical isolation and localized inbreeding of eri silkworm populations. Those from the different altitudes have shown significant phenotypic variation due to varied gene expression. Moreover, 118 loci $(60 \%)$ have given evidence of deviation from H-W E. Presumably, in different geographic locations, natural selection acts on different genomic regions (Weinig et al., 2003; Mitchell-Olds and Schmitt, 2006). Fragmented populations are highly susceptible to those environmental factors capa- ble of inducing genetic divergence (Antonovics, 1976; Willi et al., 2006). Herein, an attempt was made to employ molecular markers for assessing genetic hazard due to fragmentation of habitats, and the subsequent impact on eri-subpopulation differentiation. In these populations, the positive correlation between geographic and genetic distances clearly indicated the effect of geographical isolation on genetic structure. On the contrary, in Cachar (altitude: 680MSL) from lower Assam and Dhakuakhana (altitude: $68 \mathrm{MSL}$ ) from upper Assam, there was both phenotypical and genotypical proximity, as well as joint grouping on the phylogram. These populations presented low genetic polymorphism (28\%), relatively lesser observed alleles $(1.2 \pm 0.4)$ and lower gene diversity $(\mathrm{h}=0.09$ and 0.11 respectively), apparently through deficient selection in patchy habitats. Nevertheless, in the commercial populations (E3 to E8), the grouping together in the phylogram indicated genetic similarity, due to the continuous multiplication by inbreeding and/or genetic mixing through human intervention.

The increased rate of inbreeding and genetic drift can be considered as possible causes of erosion in genetic diversity in small eri populations (Keyghobadi et al., 2005; Ouma et al., 2005). Wide-spread linkage disequilibrium, a further indication of recuperated allelic variability, gives added support to this hypothesis. The decrease in disequilibrium with the increase in altitude implies low genetic diversity in high-altitude populations. Tests showed $\mathrm{D}^{2} \mathrm{ST}>\mathrm{D}^{2} \mathrm{IS}$ to be an indication that disequilibria was more pronounced among S.c.ricini subpopulations. In contrast, $\mathrm{D}^{2} \mathrm{IS}>\mathrm{D}{ }^{2} \mathrm{ST}$ implies a significant contribution of random genetic drift to the increase in disequilibrium variance (Ohta, 1982). Such random fluctuation is enhanced by the differentiation in those subpopulations (Ohta, 1982) that presents low genetic variation (Hedrick, 2000; Vuorinen and Eskelinen, 2005). Although less loci deviating from $\mathrm{H}-\mathrm{WE}$ within the different subpopulations can be an indication of allele fixation by natural selection under geographical isolation, random drift may also have induced population differentiation under conditions of low gene migration.

A significant decrease in gene diversity coinciding with the increase in altitude ( 35 to $900 \mathrm{MSL}$ ) in eri populations places in evidence the influence of the heterogeneous topographical conditions of northeast India on population build-up, as reported for Drosophila melanogaster (Hoffmann et al., 2001; Anderson et al., 2005) and other animals (Pariset et al., 2009), under varying geographical conditions. Continuous mountain ranges, by restricting gene flow between scattered populations, have contributed significantly to the large-scale inbreeding, excess of homozygotes and stabilization of divergent sub-populations, which have ultimately led to the Wahlund effect (Wahlund, 1928), as noticed earlier in Anopheles arabiensis (Kamau et al., 2007), the Atlantic dipteran, Ochlerotatus taeniorhynchus (Bello and Becerra, 2009), and wild popu- 
lations of the muga silkworm, Antheraea assama (Arunkumar et al., 2009). The availability of local congenial survival conditions was evident by most of the eri populations having been uniformly distributed on the ALSCAL matrix. Despite low gene diversity, the high survival rate $(\sim 90.52 \%)$ indicated the voidance of threshold genediversity for survival. Notably, most of the loci that deviated from H-WE revealed high F-values and a tendency towards homozygosity, thus enhancing their dominance in eri subpopulations. High homozygosity, homogeneous distribution and the high survival rate exerted a positive influence on genes favorable for fitness, thus confirming the significant association between alleles and fitness traits that contribute to the survival (Schulze and McMahon, 2002; Lyons et al., 2009) of eri populations under environmental stress (e.g. high altitudes), instead of high heterozygosity, which tends to be non-heritable.

\section{Differentiation of sub-populations}

By plotting the phylogram onto a geographic map, the intermediate geo-genetic positions of the Barpathar and Chuchuyimlang populations in northeast India became apparent. But the absence of intermediate status, on comparing phenotypic traits in them with other eri populations, indicated the independency of genetic expression. Moreover, the low hatching rate $(\sim 70 \%)$ indicated instability in expressing an important fitness trait. Geographically, whereas Barpathar is situated at a low altitude (99 MSL), Chuchuyimlang is at higher altitude (925 MSL). Polymorphism was $43 \%$ in the Barpathar population and $27 \%$ in the Chuchuyimlang. Gene diversity in both was low $(\mathrm{h}=0.161$ and 0.092 respectively), whereas genetic distance to other populations was proportionately higher $($ mean $=0.349$ ). DFA grouping of these populations with those at low altitudes revealed mutual genetic closeness. Such an unstable genetic structure is mostly due to the loss of rare alleles by a slower-rate drift (Cornuet and Luikart, 1996). The low hatching rate, coupled with low gene-diversity and intermediate geo-genetic positioning, imply their origin by chance hybridization, but with reduced hybrid fitness (Peterson et al., 2005). Gene diversity in these eri sub-populations may also be influenced by non-genetical parameters, preferably geographical mountain-barriers, variations in altitude, low flying capacity, etc., that are non-supportive to natural hybridization. Alternatively, genetic grouping of these geographically separated populations supposes genetic invasiveness and subsequent intra-habitat adaptation. How invasion occurred requires further investigation.

In the Lakhimpur population, situated at $102 \mathrm{MSL}$, both polymorphism $(58 \%)$ and gene diversity $(\mathrm{h}=0.155)$ were higher, when compared with the others. Individuals hereof were separated into core and peripheral groups, with an intermediate genetic distance of 0.263 . Segregation of the peripheral population may be due to partial isolation of the population where non-adaptive inbreeding permits nat- ural selection to enter into play (Charlesworth and Wright, 2001), which possibly induced the deviation from H-WE. Most of the quantitative traits of the Lakhimpur population showed intermediate values, an indication that natural selection had played upon different traits. The shift can possibly be associated with changes in habitat also (Calsbeek et al., 2009). Such genetic reorganization within the Lakhimpur sub-population is an indication of the occurrence of ecological devastation with genetic consequences in the Brhmaputra river valley.

Genetic distances among eri populations increased with the increase in altitude and geographical distance. The low gene diversity in high-altitude populations could be attributed to geographic isolation by mountain-barriers, low gene flow due to long-distance flying incapacity of the moths, and the enhanced action of drift in patchy habitats (Barrett and Kohn, 1991; Leimar, 2009). Notably, patchy habitat induces low genetic variability, high linkage disequilibrium and colonization of new subpopulations. Such genetic pressure leads to discrete modes of selection, thus causing plasticity in phenotypes under varying environmental conditions. Thus, the revelation of the challenges faced by scattered subpopulations, through the interaction between genomic and ecological processes, will help both in evaluating the total eri population status, and conserving the original S. c. ricini gene pool. Both enlargement in the effective size of subpopulations and habitat protection are essential for maintaining genetic variability and increasing gene flow among eri populations. A strongly differentiated subpopulation, as that of Lakhimpur, is to be considered as an evolutionarily active habitat for conservation planning.

\section{Acknowledgments}

The authors are thankful to the anonymous referees for their critical reading and to the Central Silk Board, Government of India, for financial support in the form of research project AIG 3323.

\section{References}

Anderson AR, Hoffmann AA, McKechnie SW, Umina PA and Weeks AR (2005) The latitudinal cline in the In(3R) Payne inversion polymorphism has shifted in the last 20 years in Australian Drosophila melanogaster populations. Mol Ecol 14:851-858

Anderson TW (1984) An Introduction to Multivariate Analysis. 2nd edition. Wiley, New York, 704 pp.

Antonovics J (1976) The nature of limits to natural selection. Ann Missouri Bot Gard 63:224-247.

Arunkumar KP, Tomar A, Daimon T, Shimada T and Nagaraju J (2008) Wild Silkbase: An EST database of wild silkmoths. BMC Genomics 9:e338.

Arunkumar KP, Kifayathullah L and Nagaraju J (2009) Microsatellite markers for the Indian golden silkmoth, Antheraea assama (Saturniidae, Lepidoptera). Mol Ecol Res 9:268270. 
Barrett SH and Kohn JR (1991) Genetic and evolutionary consequences of small population size in plants: Implications for conservation. In: Falk DA and Holsinger KE (eds) Genetics and Conservation of Rare Plants. Oxford University Press, Oxford, pp 1-15.

Bello F and Becerra V (2009) Genetic variability and heterogeneity of Venezuelan equine encephalitis virus vector Ochlerotatus taeniorhynchus (Diptera, Culicidae) populations of the Colombian Atlantic coast, based on microsatellite loci. Genet Mol Res 8:1179-1190.

Calsbeek R, Buermann W and Smith TB (2009) Parallel shifts in ecology and natural selection in an island lizard. BMC Evol Biol 9:e3.

Charlesworth D and Wright S (2001) Breeding system and genome evolution. Curr Opin Genet Dev 11:685-690.

Cornuet JM and Luikart G (1996) Description and power analysis of two tests for inferring recent population bottlenecks from allele frequency data. Genetics 144:2001-2014.

Culley TM, Wallace LE, Gengler-Nowak KM and Crawford DJ (2002) A comparison of two methods of calculating $G_{s t}$, a genetic measure of population differentiation. Am J Bot 89:460-465.

Davies KF, Gascon C and Margules CR (2001) Habitat fragmentation: Consequences, management, and future research priorities. In: Soule ME and Orians GH (eds) Conservation Biology: Research Priorities for the Next Decade. Island Press, Washington DC, pp 81-97.

Ehtesham NZ, Bentur JS and Bennett J (1995) Characterization of a DNA sequence that detects repetitive DNA elements in the Asian gall midge (Orseolia oryzae) genome: Potential use in DNA fingerprinting of biotypes. Gene 153:179-183.

Hale ML, Lurz PW, Shirley MD, Rushton S, Fuller RM and Wolff K (2001) Impact of landscape management on the genetic structure of red squirrel populations. Science 293:22462248.

Hedrick PW (2000) Genetics of Populations. 2nd edition. Jones \& Barlett, Sudbury, 553 pp.

Hoffmann AA, Hallas R, Sinclair C and Mitrovski P (2001) Levels of variation in stress resistance in Drosophila among strains, local populations, and geographic regions: Patterns for desiccation, starvation, cold resistance, and associated traits. Evolution 55:1621-1630.

Introna Jr F, Di VG, Campobasso CP and Dragone M (1997) Sex determination by discriminant analysis of Calcanei measurements. J Forensic Sci 42:725-728.

Kamau L, Munyekenye GO, Vulule JM and Lehmann T (2007) Evaluating genetic differentiation of Anopheles arabiensis in relation to larval habitats in Kenya. Infect Genet Evol 7:293-297.

Keyghobadi N, Roland J, Matter SF and Strobeck C (2005) Among- and within-patch components of genetic diversity respond at different rates to habitat fragmentation: An empirical demonstration. Proc R Soc Lond B Biol Sci 272:553-560.

Kimura M and Crow JF (1964) The number of alleles that can be maintained in a finite population. Genetics 49:725-738.

Leimar O (2009) Environmental and genetic cues in the evolution of phenotypic polymorphism. Evol Ecol 23:125-135.

Lewontin RC (1972) Testing the theory of natural selection. Nature 236:181-182.
Lyons EJ, Amos W, Berkley JA, Mwangi I, Shafi M, Williams TN, Newton CR, Peshu N, Marsh K, Scott JAG, et al. (2009) Homozygosity and risk of childhood death due to invasive bacterial disease. BMC Med Genet 10:e55.

Mahalanobis PC (1936) On the genetical distance in statistics. Proc Nat Inst Sci India 2:265-275.

Mitchell-Olds T and Schmitt J (2006) Genetic mechanisms and evolutionary significance of natural variation in Arabidopsis. Nature 441:947-952.

Nagaraju J, Kathirvel M, Kumar RR, Siddiq EA and Hasnain SE (2002) Genetic analysis of traditional and evolved Basmati and non-Basmati rice varieties by using fluorescence-based ISSR-PCR and SSR markers. Proc Natl Acad Sci USA 99:5836-5841.

Nei M (1972) Genetic distance between populations. Am Nat 106:283-292.

Nei M (1973) Analysis of gene diversity in subdivided populations. Proc Natl Acad Sci USA 70:3321-3323.

Nei M and Li H (1979) Mathematical model for study the genetic variation in terms of restriction endonucleases. Proc Natl Acad Sci USA 74:5267-5273.

Ohta T (1982) Linkage disequilibrium due to random genetic drift in finite subdivided populations. Proc Natl Acad Sci USA 79:1940-1944.

Ouma JO, Marquez JG and Krafsur ES (2005) Macrogeographic population structure of the tsetse fly, Glossina pallidipes (Diptera, Glossinidae). Bull Entomol Res 95:437-447.

Pariset L, Cuteri A, Ligda C, Ajmone-Marsan P, Valentini A and ECONOGENE Consortium (2009) Geographical patterning of sixteen goat breeds from Italy, Albania and Greece assessed by Single Nucleotide Polymorphisms. BMC Ecology 9:e20.

Peterson, MA, Honchak BM, Locke SE, Beeman TE, Mendoza J, Green J, Buckingham KJ, White MA and Monsen KJ (2005) Relative abundance and the species-specific reinforcement of male mating preference in the Chrysochus (Coleoptera, Chrysomelidae) hybrid zone. Evolution 59:2639-2655.

Piegler RS and Naumann S (2003) A Revision of the Silkmoth Genus Samia. University of Incarnate Word, San Antonio, pp 227.

Pradeep AR, Chatterjee SN and Nair CV (2005) Genetic differentiation induced by selection in an inbred population of the silkworm Bombyx mori, revealed by RAPD and ISSR marker systems. J Appl Genet 46:291-298.

Pradeep AR, Anuradha HJ and Raje Urs S (2007) Molecular markers for biomass traits: Association, interaction and genetic divergence in Silkworm Bombyx mori. Biomarker Insights 2:197-217.

Pradeep AR, Awasthi AK and Raje Urs S (2008) Association of $\mathrm{A} / \mathrm{T}$ rich microsatellites with responses to artificial selection for larval developmental duration in the silkworm Bombyx mori. Mol Cell 25:467-478.

Santana QC, Coetzee MPA, Steenkamp ET, Mlonyeni OX, Hammond GNA, Wingfield MJ and Wingfield BD (2009) Microsatellite discovery by deep sequencing of enriched genomic libraries. Biotechniques 46:217-223.

Saravanakumar R, Ponnuvel KM and Qadri SMH (2010) Genetic stability analysis of diapause-induced multivoltine silkworm Bombyx mori germplasm using inter simple sequence repeat markers. Entom Exp Appl 135:170-176. 
Schlotterer C (2000) Evolutionary dynamics of microsatellite DNA. Chromosoma 109:365-371.

Schulze TG and McMahon FJ (2002) Genetic association mapping at the crossroads: Which test and why? Overview and practical guidelines. Am J Med Genet (Neuropsych Genet) 114:1-11.

Singh KC and Benchamin KV (2002) Biology and ecology of the eri silkmoth, Samia ricini (Donovan) (Saturniidae): A review. Bull Ind Acad Sericult 6:20-33.

Suzuki, Y, Gage L and Brown DD (1972) The genes for silk fibroin in Bombyx mori. J Mol Biol 70:637-649.

Swofford DL (1998) PAUP*: Phylogenetic analysis using parsimony (*and other methods), v. 4. Sinauer, Sunderland.

Vijayan K, Nair CV, Kar PK, Mohandas TP, Sarathchandra B and Urs SR (2005) Genetic variability within and among three ecoraces of the tasar silkworm Antheraea mylitta Drury, as revealed by ISSR and RAPD markers. Int J Indust Entomol 10:51-59.

Vijayan K, Anuradha HJ, Nair CV, Pradeep AR, Awasthi AK, Saratchandra B, Rahman SAS, Singh KC, Chakraborti R and Urs SR (2006) Genetic diversity and differentiation among populations of the Indian eri silkworm, Samia Cynthia ricini, revealed by ISSR markers. J Insect Sci 6:e30.

Vuorinen JA and Eskelinen O (2005) Long-term stability of allozyme frequencies in a wood lemming, Myopus schisticolor, population with biased sex ratio and density fluctuations. Heredity 94:443-447.

Wahlund S (1928) Zusammensetzung von Population und Korrelationserscheinung vom Standpunkt der Vererbungslehre aus betrachtet. Hereditas 11:65-106.

Weinig C, Dorn LA, Kane NC, German ZM, Halldorsdottir SS, Ungerer MC, Toyonaga Y, Mackay TFC, Purugganan MD and Schmitt J (2003) Heterogeneous selection at specific loci in natural environments in Arabidopsis thaliana. Genetics 165:321-329.

Weir BS (1979) Inferences about linkage disequilibrium. Biometrics35:235-254.

Willi Y, Van Buskirk J and Hoffmann AA (2006) Limits to the adaptive potential of small populations. Ann Rev Ecol Evol Syst 37:433-458.

Young FW, Easterling DV and Forsyth BN (1984) The general Euclidean model for scaling three mode dissimilarities: Theory and application. In: Law HG, Snyder Jr GW, Hattie J and McDonald RP (eds) Research Methods for Multi-Node Data Analysis in the Behavioral Sciences. Praeger, New York, pp 440-465.

Young FW and Harris DF (1990) Multidimensional scaling: Procedure ALSCAL. In: Norusis M (ed) SPSS Base System: Users' Guide. SPSS, Chicago, pp 397-461.

Zietkiewicz E, Rafalski A and Labuda D (1994) Genome fingerprinting by simple sequence repeats (SSR)-anchored polymerase chain reaction amplification. Genomics 20:176-183.

\section{Internet Resources}

Yeh FC (1998) POPGENE16, v. 1.31. Agriculture and Forestry, Molecular Biology and Biotechnology Center, University of Alberta and Center for International Forestry Research, http://www.ualberta.ca/ fyeh.

Associate Editor: Louis Bernard Klaczko

License information: This is an open-access article distributed under the terms of the Creative Commons Attribution License, which permits unrestricted use, distribution, and reproduction in any medium, provided the original work is properly cited. 